\section{上肢・下肢の届能力について（第2 羟）}

富山大学 山 㴋 利 交

\section{(1) 腥}

1958 年本校の体育尃攻学生, 男 21 才，女 20 才の各

17 名の体格，筋力等を測定し，1951 年男 12 名女 4 名の るのと比較し次の結果を得た。

\section{(I) 珝定结果}

筋力湘定は東大石河氏の腕エルメメーターを使用し た。

No. 1

\begin{tabular}{|c|c|c|c|c|c|c|c|c|}
\hline & 量 & 体点 & 尚照 & 全畗 & 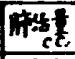 & 地加去 & N贺 & 苏的妿 \\
\hline $21 \mathrm{MU}^{2}$ & 1682 & $\begin{array}{l}61.2 \\
3 \times 3 \\
7.8\end{array}$ & 982 & $\begin{array}{c}9 \% 9 \\
3,4 \\
\end{array}$ & $\begin{array}{l}76,32 \\
687\end{array}$ & 51.9 & $\begin{array}{r}47.5 \\
5.8 \\
\end{array}$ & $\begin{array}{l}75.3 .8 \\
1,6.9\end{array}$ \\
\hline 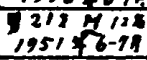 & 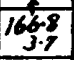 & $5,5 \times 8$ & 8र.द & 90.7 & of & $\begin{array}{r}47.3 \\
77.2 \\
\end{array}$ & $8 \%$ & $\begin{array}{c}159.3 \\
3 / 8 \\
3 / 8\end{array}$ \\
\hline 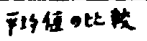 & Ebi & thi & $16 \mathrm{i}$ & $2 r_{2} c^{2}$ & 125: & 145 & $\frac{25 i}{4}$ & As;i \\
\hline $\begin{array}{l}209 M^{176} \\
99242-71\end{array}$ & 15.45 & $\begin{array}{l}51.9 \\
5.6\end{array}$ & 82.9 & $\begin{array}{l}85.6 \\
3.1 \%\end{array}$ & 2935 & $\begin{array}{r}32.4 \\
4.8 \\
4\end{array}$ & 28.6 & $\begin{array}{l}94: 5 \times x \\
80.1\end{array}$ \\
\hline 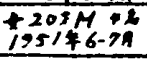 & 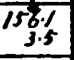 & 53.5 & $8 \% 1.3$ & 85.1 & 2935 & 30.3 & $\begin{array}{l}28.0 \\
3.4\end{array}$ & $105: 0$ \\
\hline 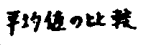 & tsi & tri & Hai & $\operatorname{lat}$ & $t_{2} b_{i}$ & fori & thi & Eri \\
\hline $3+375$ & 有音 & t意 & t五 & th & $t$ & 南意 & 古巷 & 曹意 \\
\hline
\end{tabular}

No. 2

\begin{tabular}{|c|c|c|c|c|c|c|c|c|}
\hline 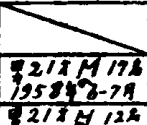 & $\frac{1}{20.3}$ & \begin{tabular}{|l}
1922 \\
1,7 \\
1,6
\end{tabular} & $\begin{array}{l}17 \% 4 \\
6.0\end{array}$ & $\frac{15.8}{18.8}$ & 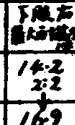 & \begin{tabular}{|c|}
5.5 \\
2.5 \\
17.4 \\
\end{tabular} & 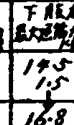 & $\frac{4}{159}$ \\
\hline $35186-79$ & & $23: 8$ & & & 3 & 3.2 & 2.8 & \\
\hline 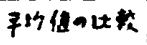 & Hai & LE: & Esi & $1 \%$ 䊉 & 5 都 & Dai & $5 \%$ 政 & $B B_{i} \mathrm{i}$ \\
\hline 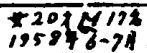 & $1 \neq 2$ & 13.3 & $\begin{array}{ll}10.9 \\
2.0\end{array}$ & 102 & $9 ; \%$ & $\begin{array}{c}0.2 \\
2 ; 4\end{array}$ & $\begin{array}{l}8.6 \\
2: 0 \\
\end{array}$ & $\begin{array}{l}9: 9 \\
2: 0\end{array}$ \\
\hline 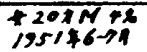 & 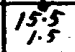 & $\begin{array}{l}14: 4 \\
7.2\end{array}$ & 13.9 & $\sqrt{1369}$ & 10.5 & 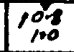 & 落, & $7,1.2$ \\
\hline 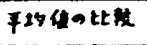 & $16 i$ & $16 i$ & ，触: & 'z触 & In: & Eni & $\ln \frac{\pi k}{2}$ & 57. 有类 \\
\hline 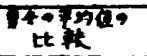 & 而意 & 克 & 车声 & th & 酸 & 苏急 & 有巷 & 克 \\
\hline
\end{tabular}

No. 3

a) 富山大学教育学部 学生 21 才男 1958 年 78 名身長 $166.3 \mathrm{~cm}$ 体重 $58.2 \mathrm{~kg}$. $85.5 \mathrm{~cm}$ 坐高 $90.7 \mathrm{~cm}$

b）全国大学 21 才男 1956 年 68,262名 70,303名身 長 $165.9 \pm 5.4 \mathrm{~cm}$ 体重 $56.6 \pm 5.8 \mathrm{~kg}$ 腩 $84.5 \pm 4.3 \mathrm{~cm}$ 坐高 $90.2 \pm 3.2 \mathrm{~cm}$

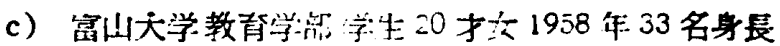

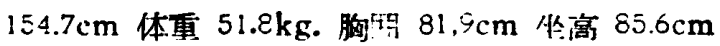

d）企国大学 20 寸女 1950 年 15,560名～15,993名身 長 $154.5 \pm 4.5 \mathrm{~cm}$ 体重 $50.2 \pm 5.3 \mathrm{~kg}$. 胸明 $30.7 \pm 4.7 \mathrm{~cm}$ 坐高 $84.1 \pm 2.6 \mathrm{~cm}$

e) 最大耐筋力

上肢 男女の比 右 $68 \%$ 庘 $69 \%$ 右左の比 男 $92 \%$ 女 $93 \%$

下肢 男女の比 右 $66 \%$ 左 $66 \%$ 右左の比 男109\% 女109\%

f）最大屈筋力

上肢 男女の比 右 $63 \%$ 左 $65 \%$ 在左の比男 $91 \%$ 女 $94 \%$

下肢 男女の比 右 $59 \%$ 左 $62 \%$ 右左の比 男110\% 女115\%

\section{(I) 蛣语}

（1）身長・体重・胸囲・坐高・阨活量・提力等の体 格の笔育状況は男女共 1951 年上りも上算の傾向を示し ている（1958 年の本学部学生区び 1956 作の全国大学々 生の平均上りる優る). 然し背筋力・上肢下肢の最大耐 筋力・最大屈箭力等におい、ては逆に娍少の傾向を示して いる・

（2）平均值の比較では，男の上肢，左最大屈矨力， 下肢右最大的筋力，右最大屈筋力に 有意の 羑が認めら れ，女子では上肢，下肢共右左の最大屈笳力に有意の差 があり，共に今年の方が劣っている。

（3）この年令庴におげる男女間に:は甚しい筋力差が 認めら九る・上肢, 下肢の最大耐筇力, 最大屈筋力共女 子は男子の60〜 70\%にあたる。

（4）上肢汇括いては，男女共最大的胳力，最大屈筋 力共に左方は右方の 91 94\%首にあたるか，下肢におい ては両筋力共逆に 方方が右方上り強い傾向が認められ る. 右左の比は男女共 109〜115\%，この傾向:さ7 年前 よりも明暸になつている。 